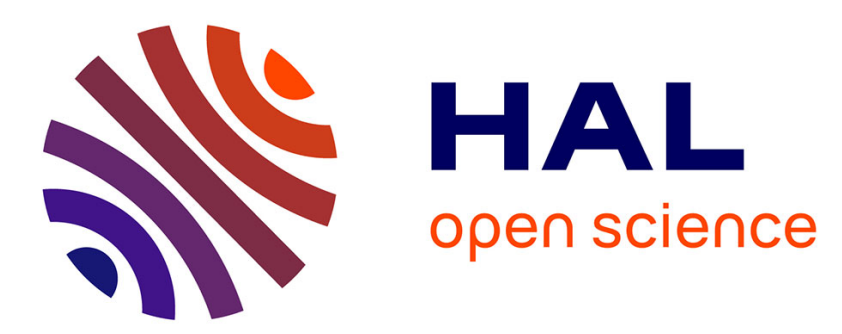

\title{
Combined Electrical Faults Detection and Diagnosis Using Current Signature Analysis
}

Amel Hadri Hamida, Frédéric Kratz, Ouafae Bennis, Fatima Babaa

\section{To cite this version:}

Amel Hadri Hamida, Frédéric Kratz, Ouafae Bennis, Fatima Babaa. Combined Electrical Faults Detection and Diagnosis Using Current Signature Analysis. SDEMPED21 13th edition of the IEEE International Symposium on Diagnostics for Electric Machines, Power Electronics and Drives, Aug 2021, DALLAS, United States. hal-03273263

\section{HAL Id: hal-03273263 https://hal.science/hal-03273263}

Submitted on 29 Jun 2021

HAL is a multi-disciplinary open access archive for the deposit and dissemination of scientific research documents, whether they are published or not. The documents may come from teaching and research institutions in France or abroad, or from public or private research centers.
L'archive ouverte pluridisciplinaire HAL, est destinée au dépôt et à la diffusion de documents scientifiques de niveau recherche, publiés ou non, émanant des établissements d'enseignement et de recherche français ou étrangers, des laboratoires publics ou privés. 


\title{
Combined Electrical Faults Detection and Diagnosis Using Current Signature Analysis
}

\author{
F. Babaa, O. Bennis, F. Kratz, A. Hadri-Hamida
}

\begin{abstract}
Safety, disponibility, and continuity of industrial systems are major concern topics in maintenance". A key entity in the production chain is the asynchronous machine. Because of its critical role in different areas of production, its maintenance and monitoring remains of undisputed importance. During its operating time, the machine may be subject to various malfunctions like stator or rotor defects, demonstrating the absolute need for its regular diagnosis. This work provides new elements about the diagnostic in case of combined faults between turn to turn short circuit fault and unbalanced supply voltage using current signature analysis. These faults features will be analyzed through frequency domain parameters, and component harmonics spectrum analysis. The study of this combined electrical defect will be able to clearly and definitively define the fault index specific to the short-circuit fault. Simulation and experimental results validate the hypothesis.
\end{abstract}

Index Terms-Turn to turn short circuit fault, unbalanced voltage supply, FFT spectrum, harmonics components, MCSA method

\section{INTRODUCTION}

$\mathrm{T}$

HREE-PHASE squirrel cage induction motor is frequently used because of its reliability, versatility, robust construction, low cost and high performance. Those attributes satisfy an essential demand of the industry: safe and reliable operations on rotating machines.

Reducing maintenance costs, reducing mean time to repair and preventing unscheduled downtimes, which result in lost production and financial income, are the priorities of electrical drive manufacturers and operators.

Correct diagnosis and early detection of emerging defects allows for immediate maintenance and a short interruption of the system.

A suitable diagnostic method should take only a few key measurements to analyze a machine and a diagnosis indicator of incipient failure modes in a minimum time [113].

In a healthy situation, the currents are balanced and the impedances of stator and rotor are identical. In this case, only the normal frequency components in stator and rotor current, at $f_{s}$ and $\mathrm{s} f_{s}$ respectively those exist, where $f$ is the power grid frequency and $\mathrm{s}$ the slip.

\footnotetext{
F. Babaa is with Electrical Laboratory of Constantine "LEC", University of Constantine 1, 25000 Constantine, ALGERIA

(e-mail: babaa.fatima@yahoo.fr).

O. Bennis is with PRISME Laboratory, University of Orleans, 28000 Chartres, FRANCE (e-mail: ouafae.bennis@univ-orleans.fr).

F. Kratz is a Professor with the Department of Industrial Risk Control, INSA Centre Val de Loire, Bourges, FRANCE.

(e-mail: frederic.kratz@insa-cvl.fr).

A. Hadri-Hamida is with LMSE Laboratory, University of Biskra,

ALGERIA (e-mail: am hadri@yahoo.fr).
}

It is also known, that any asymmetry of induction machine or any unbalanced in the voltage supply can be detected through stator current negative component.

The machine behavior is not the ideal one but no severe action must be taken into account in case of these small perturbations. When supply voltage is unbalanced, the symmetry of the machine is lost and a reverse rotating magnetic field is produced. Then, a frequency component appears in the stator current at frequency $-f_{s}$.

This negative order frequency $\left(-f_{s}\right)$ is translated in the rotor by the frequency component $(s-2) f_{s}$, which generates a pulsating torque and a speed oscillation at $2 f_{s}$ frequency.

This frequency generates both a reaction current at frequency $(s-2) f$ and a new component at the frequency $(s+2) f$.

This new component produces new components in the stator currents at frequencies $\pm 3 f$, and the process starts again [4-14].

However, augmentation of these components is also results from an inter-turn short-circuit fault or any other disturbance that can affect the machine during his life. The most inconvenient disturbance for the machine is when the supply voltage is unbalanced.

That is why, the separation of harmonics due to the supply unbalanced with those originated by the stator fault is a difficult step.

For this reason, the analysis of the degradation of the performance of the induction motor under conditions of unbalanced supply voltage is very important [8-9]. The main purpose of this article is to give an accurate indicator of the turn-to-turn fault under unbalanced voltage supply using MCSA method. The validity of the advanced theory is confirmed by comparison with simulation and experimental results.

\section{CURRENT SIGNATURE ANALYSIS METHOD}

Motor Current Signature Analysis is a method to diagnose and prognose the induction machines.

Several studies use this method for fault detection and identification $[8,16,18]$. It can be easy to implement in industrial systems where process measurements are subject to vibration or unbalanced situations and any fault occurrence. In this method, it is not necessary to stop the machine to have the most important information about the motor. This is a crucial point for the continuity of the system. The first step of the method is fault detection, followed by its characterization through specific indication.

The main purpose of the MCSA method is to detect and analyze an electrical signal to study, in a detailed way, the variations of the harmonic components. This method can also detect the faults at an early stage and avoids a complete failure of the machine. Unfortunately, the unbalanced supply 
voltage is the most inconvenient fault that it gives the same harmonic components, a consequence of the short circuit fault.

Using this method, the objective of the article is to be able to provide a reliable fault index concern inter-turn shortcircuit fault under an unbalanced supply voltage and implement a reliable detection process-oriented to industrial systems.

\section{SiMULATION RESULTS}

MATLAB simulation results are obtained by using simulation models presented in [18]. Accurate differential equations results using the fourth-order Runge-Kutta method are presented and treated. To extract, in a precise way, information related to combined defaults, we used the waveform of the stator current before and after the application of the defect, we also present spectra of stator current to visualize, in the clearest way possible, the indices for detection and identification the shorted faults under unbalanced supply voltage circumstances.

Fig. 1 shows a detailed waveform of currents with applied $20 \%$ of inter-turn short circuit faults under imbalance voltage of $10 \%$ appearing at time $1.5 \mathrm{~s}$. The effects of combined fault are clearly shown. Also, the effect of turn-to-turn fault is highlighted through the representation of shorted circuit current. Combined inter-turn short circuit and unbalanced supply voltage fault plot of electromagnetic torque with time are represented in Fig. 2. The torque oscillations, created by the torque ripples, which are produced by the interaction of negatives and positives components, are evident.

In Fig.3 Simulation results of harmonics frequencies for no loaded condition with $10 \%$ voltage unbalance under different shorted circuit faults are shown. In this figure, a detailed plot of positive and negative harmonic distributions of the currents under $5 \%$ and $10 \%$ imbalance supply voltage respectively, for the healthy machine (Black), with $2 \%$ of inter-turn short circuits (red) and $20 \%$ of inter-turn short circuits (blue), under no-load condition are shown. We remark the predicted increase of harmonics frequencies after unbalanced supply voltage. Inverse sequence component is directly reflected after any disturbance in the machine due to faults or any asymmetries. Third negative and positive components appear as a result of torque oscillations and speed ripple at (s-2)f frequency. In the same figure (Fig.3), The red plot represents component frequencies with $10 \%$ of inter-turn short circuits under 5\% imbalance supply voltage in phase A. We notice an increase of all harmonics frequencies in line current spectra. This increase is due to the short circuit disturbance in the machine. On the other hand, when we apply an augmentation of unbalanced supply voltage percent with the same percent of inter-turn short circuit fault (the blue plot), we observe the insensitivity of the third negative sequence amplitude to unbalanced voltage. We can conclude that the third negative sequence component is significantly proportional to the percentage of shorted faults.

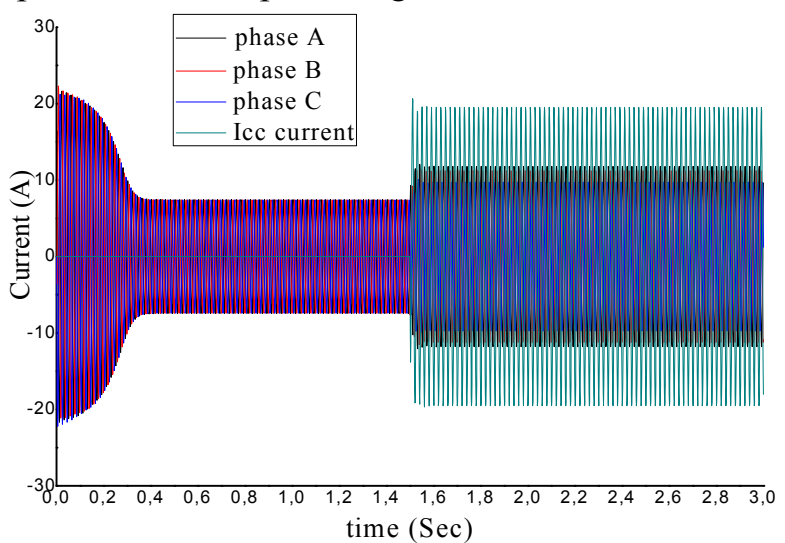

Fig. 1. Stator currents resulting from $20 \%$ inter-turn short circuits under $10 \%$ of unbalanced supply voltage with no fault and fault situation

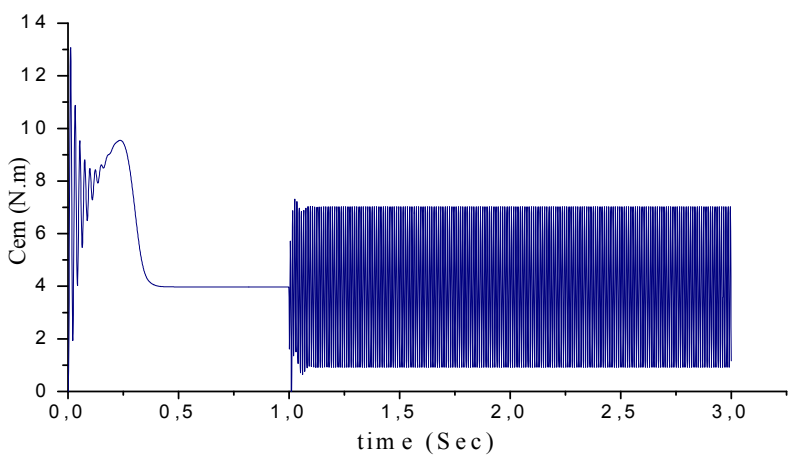

Fig. 2. Detailed waveforms of motor torque from $20 \%$ of inter turn short circuits faults under $10 \%$ of unbalanced supply voltage with no fault and fault situation
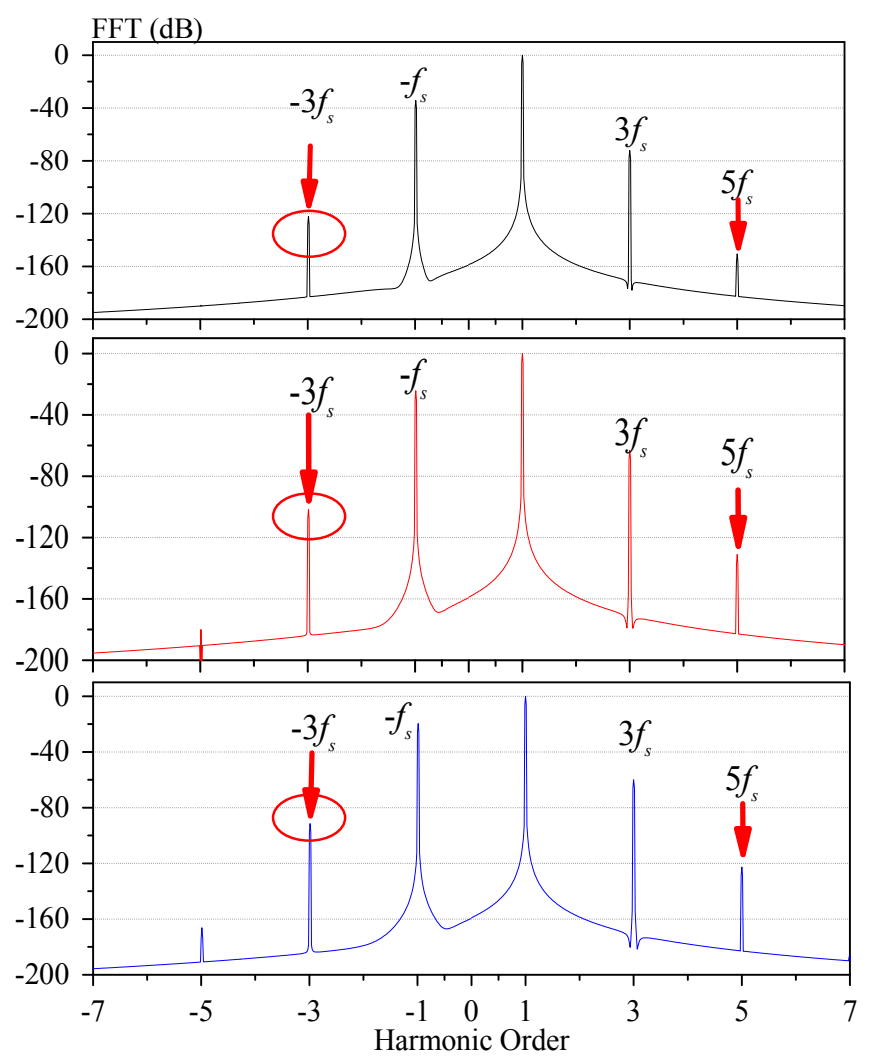

Fig.3. FFT spectrum of the stator current with combined faults: healthy machine with $5 \%$ imbalance in phase A (black), with $10 \%$ of inter-turn short circuits under 5\% imbalance supply voltage in phase A (red) and 10\% of inter-turn short circuits under $10 \%$ imbalance supply voltage in phase 1 (blue), under no load condition. 


\section{EXPERIMENTAL RESULTS}

The experimental system has been developed to study different conditions of operation of the electric machine in the healthy state or with electrical faults, like unbalanced supply voltage or inter-turn short circuit fault, under different load conditions. A magnetic powder brake is used to apply different loads.

In the test bed, the three-phase asynchronous motor, 50 $\mathrm{Hz}, 4$ poles, $1.1 \mathrm{~kW}$, rated at $400 \mathrm{~V}, 2.95 \mathrm{~A}$ and $1450 \mathrm{rpm}$ is used. To introduce the fault, we have rewound the motor with intermediate wires distributed in the three phases to be able to choose beforehand several shorted turns.

The welded connections are taken back to a terminal plate (see Fig.4) [16].

Measurements of the stator currents and voltages of the machine are performed using the voltage and current sensors. Then these values are recorded by the Le Croy Wave Runner 6050 oscilloscope which includes 4 signal acquisition channels, offers 5GS s on each ADC channel and $1 \mathrm{MB}$ of standard memory. The sampling frequency chosen for each data acquisition is $25 \mathrm{kHz}$, for a duration of $2 \mathrm{~s}$.

After the acquisition, MATLAB programs are used for frequency-domain analysis.

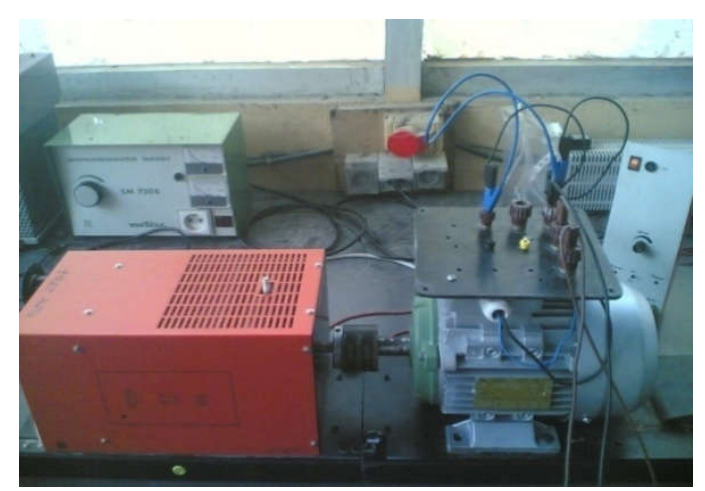

Fig. 4. View of the test bed for experimental set-up.

\section{A. Unbalanced supply voltage conditions}

When line voltages applied to an induction machine are not identical, unbalanced stator winding currents appear, the magnitude of these currents depends on the degree of unbalance. Also, a very small voltage unbalance may augment the current an extreme amount. The voltage imbalance gives a reverse current. This new current produces a negative electromagnetic force that provokes variations of certain harmonic components include in stator current. These harmonic frequencies interact with the magnetic field and aggravate the torque and speed oscillation to a double frequency $(2 f$ ). Current spectra analysis permits to filter the harmonic components and to give a large amount of spectral information.

We insert a series of resistors in one of the phases supplying and as we testing the motor under different loads. We applied different configurations of unbalancement such as $5 \%, 15 \%$, and $30 \%$ in the voltage amplitude of the concerned phase. For the calculation of the voltage unbalance factor (VUF), we use the expression of the International Electrotechnical Commission [17]
$(V U F)$ voltage unbalance factor (in \%) $=\frac{V_{n}}{V_{p}}=100 \%$

Where $V p$ and $V n$ are the amplitudes of the positive and negative sequence voltages, respectively. For example, for $15 \%, 20 \%, 36 \%$ and $60 \%$ of unbalanced supply, one obtains a VUF $5.2 \%, 7 \%, 12 \%$ and $10 \%$, respectively (show table III).

\section{B. Inter-turn short circuits faults conditions}

To introduce shorted faults, we modify the stator winding motor to have different inter-turn short-circuits, with a different number of turns and different locations along the stator windings.

The intermediate terminals at the level of two stator windings were added to allow the realization of short-circuit with different numbers of turns: $1 \%, 2 \%, 10 \%$ and $20 \%$ (see Fig. 5).

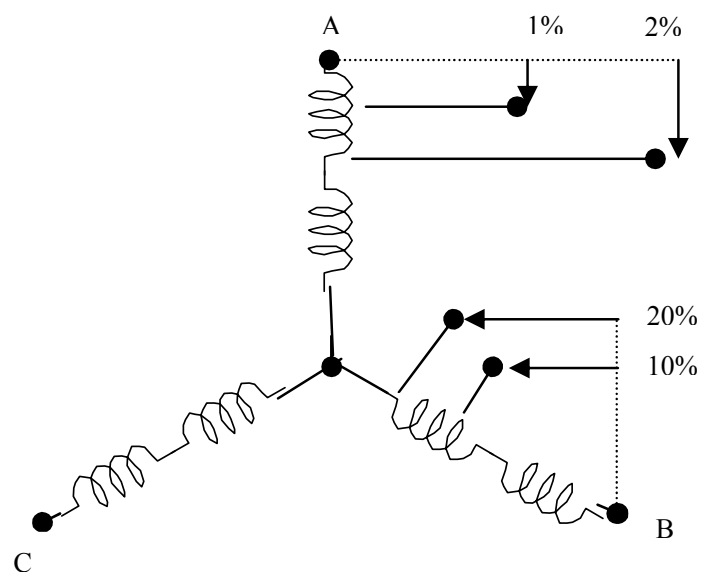

Fig. 5.View of different locations of inter-turn short circuits

In the beginning, the motor was initially tested in the absence of faults, to verify the intensity of the harmonics' amplitude before the faults (see Fig.6).

In the case of the healthy machine with $5.2 \%$ of unbalance supply voltage, the stator-current fault frequency components may become more important because of the imbalance already existing in the supply network.

However, certain frequencies $\left(-f_{s},+3 f_{s}\right)$ show observable stator currents with and without inter-turn short circuits, under unbalanced voltage supply which cannot be considered as an effective diagnostic index (see also table I and Fig.7). $-f_{s}$ is the result of any imbalance that may occur to the machine during its lifetime and a substantial increase of the $+3 f_{s}$ components can be seen when balanced power supply is replaced by unbalanced power supply. However, the $-3 f_{s}$ component clearly shows up due to the presence of a fault. This confirms the observations derived from Table II and Fig.9. In order to verify the validity of the advanced theory, figure 7 was presented. When the fault occurs, we clearly see the increase of the component $-3 f_{s}$, according to the phenomena. Nevertheless, the proportionality to the number of turns in a short circuit is not yet clear. The harmonic $-3 f_{s}$ testifies to the presence of the 
defect, on the contrary, the harmonic $+3 f_{s}$ sees its amplitude very little influenced by the defect. (see also table III and Fig.10).

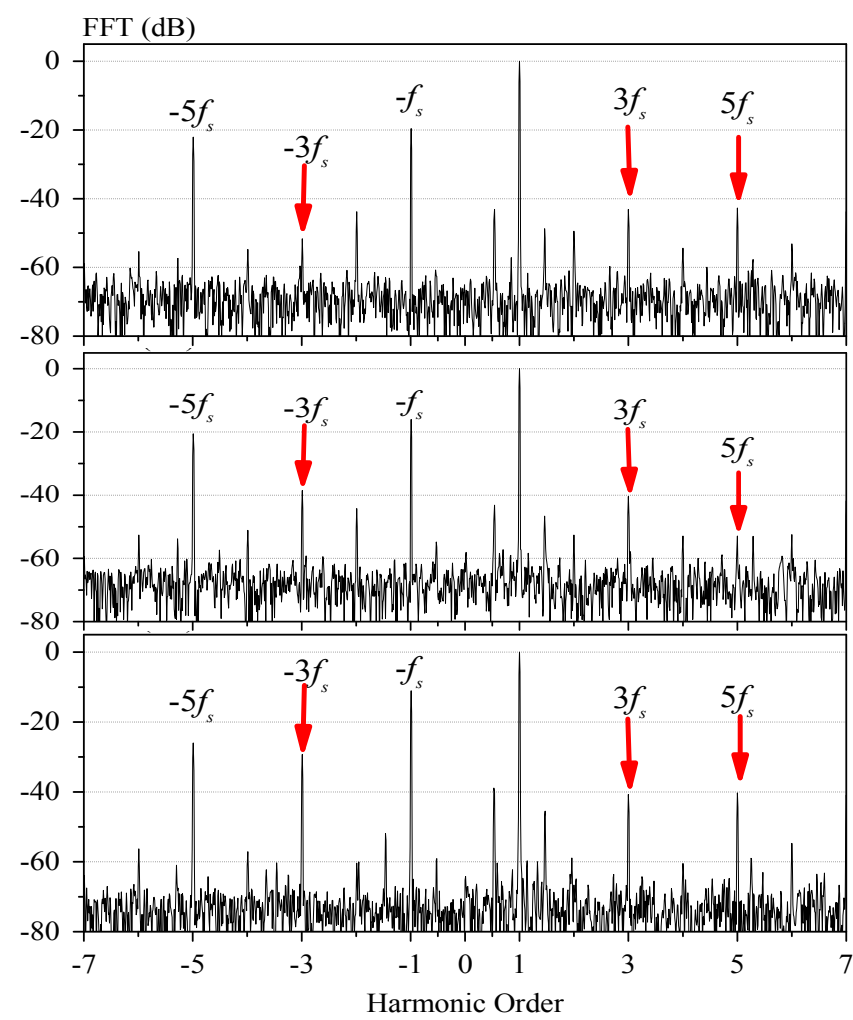

Fig.6.Normalized FFT spectrum of the stator current: healthy machine under $5.2 \%$ of unbalance supply voltage (top), with $10 \%$ of inter-turn short circuits under $20 \%$ of unbalance supply voltage (middle) and $20 \%$ of interturn short circuits under $20 \%$ of unbalance supply voltage (bottom), no load condition.
TABLE I

EFFECT OF LOAD LEVEL ON THE NEGATIVE HARMONIC FREQUENCY FOR INTER-TURN FAULTS UNDER POWER IMBALANCE

\begin{tabular}{|c|c|c|c|c|}
\hline \multicolumn{5}{|c|}{$\begin{array}{l}\text { Experimental amplitude at }-f_{s}(\mathrm{~dB}) \\
\text { for different } \% \text { of machine with inter-turn short-circuits fault under power } \\
\text { imbalance }\end{array}$} \\
\hline Load level & $\begin{array}{l}\text { Machine } \\
\text { In healthy } \\
\text { condition }\end{array}$ & $\begin{array}{c}\text { Healthy } \\
\text { machine } \\
\text { Under } 5.2 \% \\
\text { of unbalance } \\
\text { supply } \\
\text { voltage }\end{array}$ & $\begin{array}{l}\% \\
\text { of inter turn } \\
\text { short-fault }\end{array}$ & $\begin{array}{l}\text { Amplitude of } \\
\text { fault }\end{array}$ \\
\hline \multirow{3}{*}{ No load } & \multirow{3}{*}{-40.19} & \multirow{3}{*}{-27.72} & $2 \%$ & -24.66 \\
\hline & & & $10 \%$ & -11.3 \\
\hline & & & $20 \%$ & -8.57 \\
\hline \multirow{3}{*}{$\begin{array}{l}25 \% \\
\text { of Full- } \\
\text { load }\end{array}$} & \multirow{3}{*}{-40.02} & \multirow{3}{*}{-28.06} & $2 \%$ & -24.35 \\
\hline & & & $10 \%$ & -12.11 \\
\hline & & & $20 \%$ & -9.11 \\
\hline \multirow{3}{*}{$\begin{array}{l}50 \% \\
\text { of Full- } \\
\text { load }\end{array}$} & \multirow{3}{*}{-42.35} & \multirow{3}{*}{-29.08} & $2 \%$ & -25.52 \\
\hline & & & $10 \%$ & -12.74 \\
\hline & & & $20 \%$ & -9.73 \\
\hline \multirow{3}{*}{$\begin{array}{l}75 \% \\
\text { of Full- } \\
\text { load }\end{array}$} & \multirow{3}{*}{-42.59} & \multirow{3}{*}{-30.95} & $2 \%$ & -27.01 \\
\hline & & & $10 \%$ & -13.84 \\
\hline & & & $20 \%$ & -10.63 \\
\hline \multirow{3}{*}{ Full-load } & \multirow{3}{*}{-45.02} & \multirow{3}{*}{-34.13} & $2 \%$ & -28.25 \\
\hline & & & $10 \%$ & -14.64 \\
\hline & & & $20 \%$ & -11.28 \\
\hline
\end{tabular}

TABLE II

EFFECT OF LOAD LEVEL ON THE THIRD NEGATIVE HARMONIC FREQUENCY FOR INTER-TURN FAULTS UNDER POWER IMBALANCE

FFT (dB)

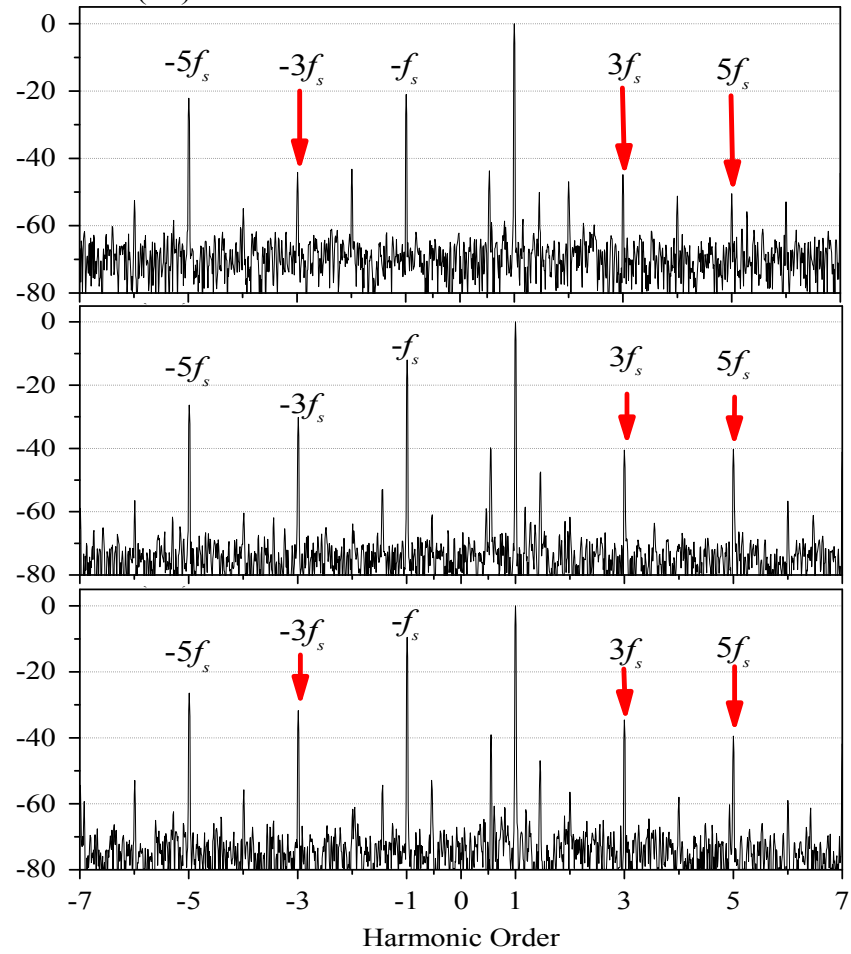

\begin{tabular}{|c|c|c|c|c|}
\hline \multicolumn{5}{|c|}{$\begin{array}{l}\text { Experimental amplitude at }-3 f_{s}(\mathrm{~dB}) \\
\text { for different } \% \text { of machine with inter-turn short-circuits fault under power } \\
\text { imbalance }\end{array}$} \\
\hline $\begin{array}{l}\text { Load } \\
\text { level }\end{array}$ & $\begin{array}{l}\text { Machine } \\
\text { In healthy } \\
\text { condition }\end{array}$ & $\begin{array}{c}\text { Healthy } \\
\text { machine } \\
\text { Under } 5.2 \% \text { of } \\
\text { unbalance } \\
\text { supply voltage }\end{array}$ & $\begin{array}{l}\% \\
\text { of inter turn } \\
\text { short-fault }\end{array}$ & $\begin{array}{l}\text { Amplitude of } \\
\text { fault }\end{array}$ \\
\hline \multirow{3}{*}{ No load } & \multirow{3}{*}{-40.19} & \multirow{3}{*}{-33.52} & $2 \%$ & -31.91 \\
\hline & & & $10 \%$ & -29.75 \\
\hline & & & $20 \%$ & -25.11 \\
\hline \multirow{3}{*}{$\begin{array}{l}25 \% \\
\text { of Full- } \\
\text { load }\end{array}$} & \multirow{3}{*}{-40.02} & \multirow{3}{*}{-35.45} & $2 \%$ & -33.51 \\
\hline & & & $10 \%$ & -29.36 \\
\hline & & & $20 \%$ & -26.73 \\
\hline \multirow{3}{*}{$\begin{array}{l}50 \% \\
\text { of Full- } \\
\text { load }\end{array}$} & \multirow{3}{*}{-42.35} & \multirow{3}{*}{-36.27} & $2 \%$ & -34.42 \\
\hline & & & $10 \%$ & -31.73 \\
\hline & & & $20 \%$ & -26.21 \\
\hline \multirow{3}{*}{$\begin{array}{l}75 \% \\
\text { of Full- } \\
\text { load }\end{array}$} & \multirow{3}{*}{-42.59} & \multirow{3}{*}{-36.66} & $2 \%$ & -34.83 \\
\hline & & & $10 \%$ & -31.65 \\
\hline & & & $20 \%$ & -27.13 \\
\hline \multirow{3}{*}{$\begin{array}{l}\text { Full- } \\
\text { load }\end{array}$} & \multirow{3}{*}{-45.02} & \multirow{3}{*}{-37.04} & $2 \%$ & -35.53 \\
\hline & & & $10 \%$ & -31.23 \\
\hline & & & $20 \%$ & -28.97 \\
\hline
\end{tabular}

Fig. 7.Normalized FFT spectrum of the stator current: healthy machine (top), with $10 \%$ of inter-turn short circuits fault under $11 \%$ of unbalance supply voltage (middle) and $10 \%$ of inter-turn short circuits under $22 \%$ of unbalance supply voltage (bottom), no-load condition. 
TABLE III

EFFECT OF LOAD LEVEL ON THE THIRD NEGATIVE HARMONIC FREQUENCY FOR INTER-TURN FAULTS UNDER DIFFERENT LEVEL POWER IMBALANCE

\begin{tabular}{|c|c|c|c|c|}
\hline & \multicolumn{4}{|c|}{$\begin{array}{l}\text { Experimental amplitude at }-3 f_{s}(\mathrm{~dB}) \\
\text { for different } \% \text { of machine with power imbalance faults under } \\
10 \% \text { of inter-turn short circuits faults }\end{array}$} \\
\hline Load level & $\begin{array}{l}\text { Machine } \\
\text { In healthy } \\
\text { condition }\end{array}$ & $\begin{array}{c}\text { Machine } \\
\text { With } 10 \% \text { of } \\
\text { inter-turn } \\
\text { short circuits } \\
\text { faults }\end{array}$ & $\begin{array}{c}\% \\
\text { of unbalanced } \\
\text { supply voltage }\end{array}$ & $\begin{array}{c}\text { Amplitude } \\
\text { of fault }\end{array}$ \\
\hline \multirow{4}{*}{ No load } & \multirow{4}{*}{-45.13} & \multirow{4}{*}{-38.18} & $10 \%$ & -36.69 \\
\hline & & & $20 \%$ & -37.35 \\
\hline & & & $36 \%$ & 36,96 \\
\hline & & & $60 \%$ & $-38,17$ \\
\hline \multirow{4}{*}{$\begin{array}{l}25 \% \\
\text { of Full- } \\
\text { load }\end{array}$} & \multirow{4}{*}{-45.43} & \multirow{4}{*}{-39.23} & $10 \%$ & -37.43 \\
\hline & & & $20 \%$ & -38.7 \\
\hline & & & $36 \%$ & $-39,51$ \\
\hline & & & $60 \%$ & $-37,34$ \\
\hline \multirow{4}{*}{$\begin{array}{l}50 \% \\
\text { of Full- } \\
\text { load }\end{array}$} & \multirow{4}{*}{-47.28} & \multirow{4}{*}{-39.50} & $10 \%$ & -38.32 \\
\hline & & & $20 \%$ & -39.08 \\
\hline & & & $36 \%$ & $-37,09$ \\
\hline & & & $60 \%$ & $-39,21$ \\
\hline \multirow{4}{*}{$\begin{array}{l}75 \% \\
\text { of Full- } \\
\text { load }\end{array}$} & \multirow{4}{*}{-48.24} & \multirow{4}{*}{-40.13} & $10 \%$ & -39.25 \\
\hline & & & $20 \%$ & -40.57 \\
\hline & & & $36 \%$ & $-41,36$ \\
\hline & & & $60 \%$ & $-39,07$ \\
\hline \multirow{4}{*}{ Full-load } & \multirow{4}{*}{-48.61} & \multirow{4}{*}{-48.75} & $10 \%$ & -40.15 \\
\hline & & & $20 \%$ & -41.73 \\
\hline & & & $36 \%$ & $-40,46$ \\
\hline & & & $60 \%$ & $-41,04$ \\
\hline
\end{tabular}

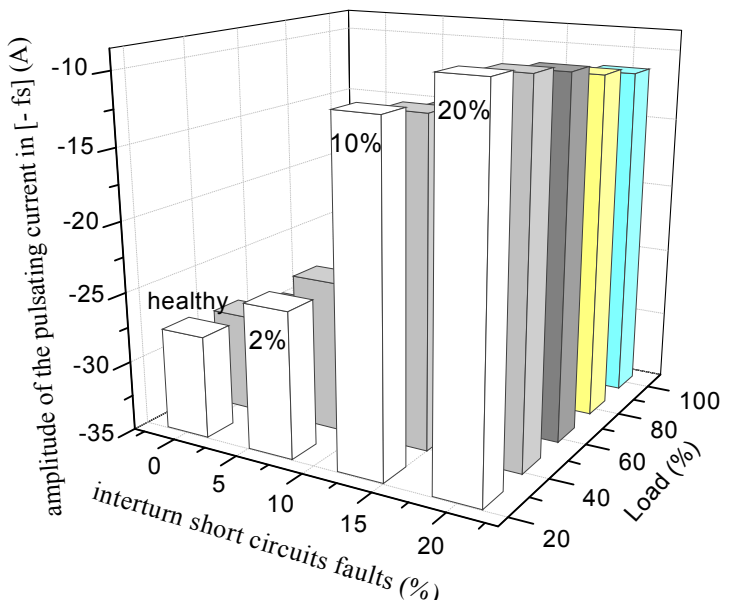

Fig. 8. 3D representation of the amplitude of the negative harmonic for different percent of unbalanced supply voltage, under $10 \%$ interturn shorted faults, no load and full-load condition.

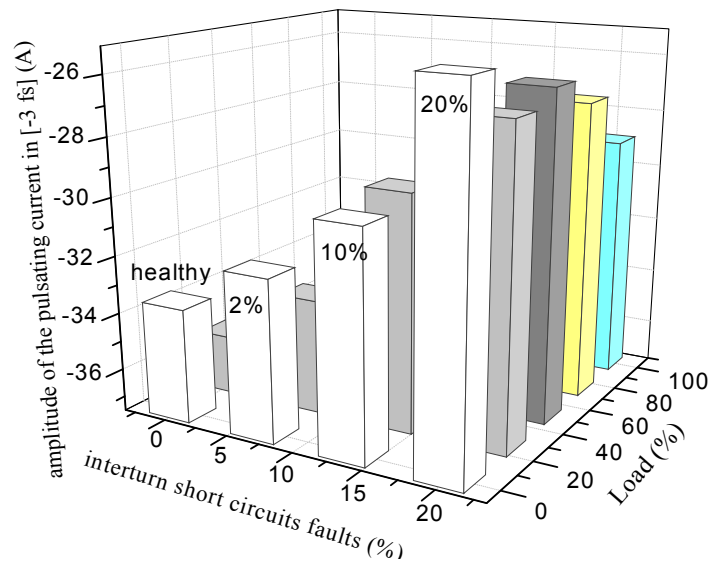

Fig. 9. 3D representation of the amplitude of the third negative harmonic for different percent of interturn shorted faults, under 5,2\% unbalanced supply voltage, no load and full-load condition.

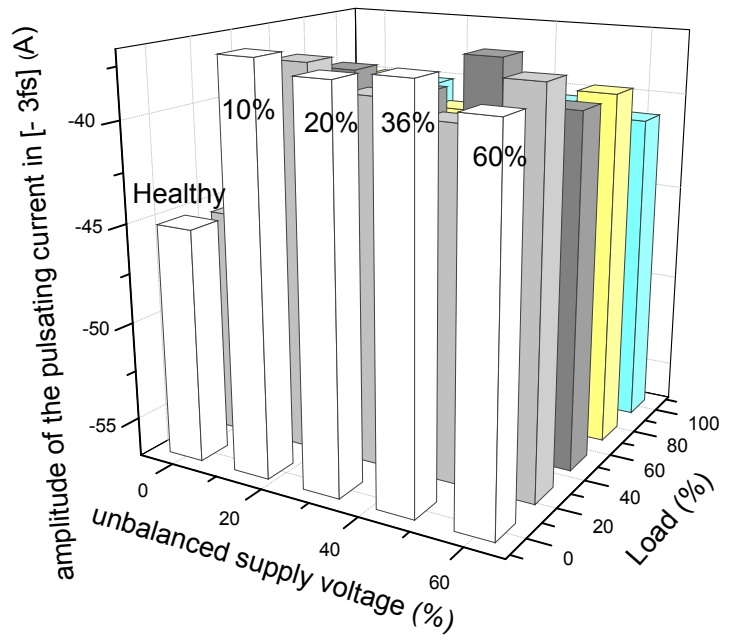

Fig. 10. 3D representation of the amplitude of the third negative harmonic for different percent of unbalanced supply voltage, under $10 \%$ inter-turn shorted faults, no load and full-load condition.

\section{CONCLUSION}

In this article, different assumptions about turn-to-turn fault under unbalanced supply voltage conditions have been issued. Through simulation and experimental results, we study the impact of unbalanced voltage when the machine is under shorted faulty conditions. It was shown that the induced harmonics in this stator current give reliable information on the stator fault condition. A study of presented results was conducted to prove that the inter-turn short circuit defaults induce particular harmonics in the stator current which were considered as default signatures. In fact, the third negative sequence component is defined as the most adequate indicator for the inter-turn short circuit fault because of its sensitiveness to the fault under unbalanced supply voltage condition. Fortunately, this new signature permits cancel the similitude between both. 


\section{REFERENCES}

[1] B. Akin, Liang Chen, Jiabin Wang, Zhigang Sun, Electromagneticthermal coupled modelling and analysis of inter-turn short-circuit faults of a permanent magnet alternator", The Journal of Engineering, IET journal, The Institution of Engineering and Technology, Volume 2019, Issue 17, June 2019, pp. 4426 - 4431.

[2] Boqiang $\mathrm{Xu}$, Zehui Zheng "SVD filtering and TLSESPRIT algorithm based on stator fault characteristic detection of dou bly-fed induction generator" The Journal of Engineering, IET Journals, The Institution of Engineering and Technology, Volume 2019, Issue 18,2019 , pp. $5193-5196$.

[3] A. Garcia-Perez, R. de Jesus Romero-Troncoso, E. Cabal-Yepez, and R. A. Osornio-Rios, "The application of high-resolution spectral analysis for identifying multiple combined faults in induction motors," IEEE Trans. Ind.Electron., vol. 58, no. 5, pp. 2002-2010, May 2011.

[4] A. Gandhi, T. Corrigan, and L. Parsa, "Recent advances in modeling and online detection of stator interturn faults in electrical motors," IEEE Trans. Ind.Electron., vol. 58, no. 5, pp. 1564-1575, May 2011.

[5] A. Garcia-Perez, R. de Jesus Romero-Troncoso, E. Cabal-Yepez, and R. A. Osornio-Rios, "The application of high-resolution spectral analysis for identifying multiple combined faults in induction motors,' IEEE Trans. Ind.Electron., vol. 58, no. 5, pp. 2002-2010, May 2011.

[6] H. Abdallah and K. Benatman, "Stator winding inter-turn shortcircuit detection in induction motors by parameter identification," IET Electric Power Applications, vol. 11, pp. 272-288, 2017.

[7] H. Henao, G.-A. Capolino, M. Fernandez-Cabanas, F. Filippetti, C. Bruzzese, E. Strangas, et al., "Trends in fault diagnosis for electrical machines: A review of diagnostic techniques," IEEE industrial electronics magazine, vol. 8, pp. 31-42, 2014.

[8] P.G. Kini, R. C. Bansal, and R. S. Aithal, "Anovel approach toward interpretation and application of voltage unbalance factor", IEEE trans. Ind. Electron., vol. 54, no. 4, pp. 2315-2322, Aug. 2007.

[9] Eyhab El-Kharashi, Joseph Girgis Massoud, "Approach to measure the degree of the unbalanced power in induction motor for energyefficient use", The Journal of Engineering, IET Journals, The Institution of Engineering and Technology, Volume 2017, Issue 8, pp 452-465.

[10] M. h. Drif and A. J. M. Cardoso, "Stator fault diagnostics in squirrel cage three-phase induction motor drives using the instantaneous active and reactive power signature analyses," IEEE Transactions on Industrial Informatics, vol. 10, pp. 1348-1360, 2014

[11] L. Xiao,H. Sun, F. Gao, S. Hou, L. Li , A New Diagnostic Method for Winding Short-Circuit Fault for SRM Based on SymmetricalComponent Analysis. Chinese Journal of Electrical Engineering, Vol.4, No.1, March 2018

[12] L. Maraaba, Z. Al-Hamouz, and M. Abido, "An Efficient Stator InterTurn Fault Diagnosis Tool for Induction Motors," Energies, vol. 11, p 653, 2018.

[13] A. Gandhi, T. Corrigan, and L. Parsa, "Recent advances in modeling and online detection of stator interturn faults in electrical motors," IEEE Trans. Ind.Electron., vol. 58, no. 5, pp. 1564-1575, May 2011.

[14] A. Berzoy, A. A. Mohamed, and O. Mohammed, "Complex-Vector Model of Interturn Failure in Induction Machines for Fault Detection and Identification," IEEE Transactions on Industry Applications, vol. 53, pp. 2667-2678, 2017.

[15] Andrzej Radecki, Stator winding inter-turn short-circuit modelling of a squirrel-cage induction motor. Power Electronics and Drives. Vol. 1(36), No. 1, 2016.

[16] Fatima Babaa, Abdelmalek Khezzar, Mohamed el kamel Oumaamar. "Experimental investigation and comparative study of interturn shortcircuits and unbalanced voltage supply in induction machines", Frontiers in Energy, 2013.

[17] P. G. Kini, R. C. Bansal, and R. S. Aithal, "A novel approach toward interpretation and application of voltage unbalance factor", IEEE Trans.Ind. Electron., vol. 54, no. 4, pp. 2315-2322, Aug. 2007.

[18] F. Babaa,O. Bennis, "An accurate inter-turn short circuit faults model dedicated to induction motors". The International Journal of Electrical and Computer Engineering (IJECE) Vol. 11 No. 1, pp 9-16, February 2021 .

\section{BIOGRAPHIES}

F. Babaa (BSc, MSC., Ph. D), received the engineer degree in electrical engineering in 2005 and the M.Sc. degree in 2007 and the Ph. D. degree in 2014 from Mentouri university 1 of Constantine, Algeria. She received the Habilitation degree from Mentouri University 1 of Constantine in 2020. Currently, she is teaching at the Electrical Engineering Institute of the
University of Constantine. Her current research interests concern diagnosis, prognosis and control systems.

O. Bennis Received the $\mathrm{Ph} \mathrm{D}$ degree in 1982 from the University of Toulouse III. She's associate professor at University of Orleans, and researcher at Prisme Laboratory France, from 1992.

F. Kratz (M'97) received the $\mathrm{Ph}$. D degree in control engineering from the University Henri Poincaré of Nancy, France, in 1991. He received the French Habilitation degree from the Institut National Polytechnique de Lorraine (INPL), France, in 1998. He is currently a Professor with the Department of Industrial Risk Control, INSA Centre Val de Loire, Bourges, France. His current research interests concern diagnosis, estimation, prognosis and reliability engineering of automatic control systems.

A. Hadri-Hamida received the engineering and MS degree in electrical engineering from Biskra University-Algeria in 2002 and 2005 respectively. She received her $\mathrm{PhD}$ in electrical engineering from Biskra University in 2011. She is currently associate professor in the department of electrical engineering at Biskra University, Algeria. Her research interests are in electronic and control systems 